\title{
Atraktor Cumi-Cumi Yang Ramah Lingkungan Dan Bertanggung Jawab di Perairan Rigaih Kabupaten Aceh Jaya
}

\section{Loligo The Actractor Area Are Entire Environment And Responsible In Rigaih Water District Aceh Jaya}

\author{
Muhammad Rizal ${ }^{1}$ \\ 1 Jurusan IImu Perikanan, Fakultas Perikanan dan ilmu Kelautan, Universitas Teuku Umar, Aceh \\ *Korespondensi: rizalmuhammadfpikutu@gmail.com
}

\begin{abstract}
ABSTRAK
Pemanfaatan sumberdaya perikanan cumi-cumi melalui kegiatan penangkapan sudah saatnya disertai dengan upaya pengaturan penangkapan dan kegiatan budidaya yang meliputi upaya pemijahan (hatchery) dan pelepasan ke alam. Upaya ini dapat memperbaiki kerusakan sumberdaya cumi-cumi karena dapat di lakukan pengkayaan stok untuk memperbaiki dan mempertahankan kelestarian sumberdaya cumi-cumi. Salah satu faktor yang sangat penting untuk mendukung upaya budidaya cumi-cumi adalah adanya ketersediaan (supply) telur dan keberhasilan pemijahan. Kawasan Rigaih Kabupaten Aceh Jaya merupaka salah satu daerah stok cumi-cumi yang sangat banyak dan ditangkap oleh nelayan tradisional setempat setiap hari. Namun sampai saat ini tidak ada dilakukan budidaya dan kegiatan lain yang menyangkut menjaga keberlanjutan cumi-cumi. Tujuan dalam pengabdian ini adalah perbedaan jenis dan kedalaman perairan tempat pemasangan atraktor terhadap penempelan telur cumi-cumi dengan menggunakan kawat besi yang dilapisi plastik hitam dan di ikat tali ijok di perairan Rigaih Kabupaten Aceh Jaya. Hasil yang diperoleh adalah Jumlah kapsul yang dihasilkan dalam sekali pemijahan berkisar 57 sampai 601 dengan jumlah telur yang terkandung di dalamnya sebanyak 124 sampai 1421 butir.
\end{abstract}

Kata Kunci : Ramah Lingkungan, Aktraktor cumi-cumi, Tanggung Jawab, Rigaih

\begin{abstract}
Utilization of fishery resources of squid through fishing activities is time to be accompanied by regulation of arrest and cultivation activities covering the effort of hatchery (hatchery) and release to nature. This effort can improve the damage of squid resources as it can be done to enrich the stock to improve and sustain the resources of the squid. One of the most important factors to support the cultivation of squid is egg supply and spawning success. The Rigaih area of Aceh Jaya Regency is one of the most diverse squid stock areas and is captured by local traditional fishermen every day. But until now there has been no cultivation and other activities related to maintaining the sustainability of squid. The purpose of this service is the difference of the type and depth of the waters where the installation of the attor to the attachment of squid eggs using black iron coated iron wire and the ijok rope tie in the waters of Rigaih Aceh Jaya Regency. The results obtained are the number of capsules produced in one spawning range 57 to 601 with the number of eggs contained in it as much as 124 to 1421 grains.
\end{abstract}

Keywords : Environmentally, Actractor, Responsibility, Rigaih

\section{PENDAHULUAN}

Sumber daya alam Perairan Indonesia yang melimpah membuat para melayan mencari jenis ikan yang memiliki nilai ekonomis yang tinggi, salah satunya adalah cumi-cumi. Pemanfaatan sumberdaya cumi-cumi ini dilakukan dengan cara penangkapan. Alat tangkap yang sering digunakan untuk menangkap organisme ini 
adalah serok, jaring angkat, beach seine, boat seine dan pancing ulur. Musim penangkapan cumi-cumi yang paling intensif adalah pada musim memijah dimana pada musim ini cumi-cumi yang tertangkap sebagian besar telah matang gonad (Tasywiruddin 1999).

Kegiatan penangkapan seperti ini apabila dibiarkan secara terus menerus dapat mengakibatkan penurunan stok cumi-cumi di alam. Hal yang sama terjadi pada penangkapan cumi-cumi dunia, sejak dua dekade penangkapan meningkat dari 1,5 juta ton di tahun 1979 menjadi 3 juta ton di tahun 1996 dan hasil tangkapan cumicumi menurun lagi pada tahun 1998 (Gappindo 1999).

Pemanfaatan sumberdaya perikanan cumi-cumi melalui kegiatan penangkapan sudah saatnya disertai dengan upaya pengaturan penangkapan dan kegiatan budidaya yang meliputi upaya pemijahan (hatchery) dan pelepasan ke alam. Upaya ini dapat memperbaiki kerusakan sumberdaya cumi-cumi karena dapat di lakukan pengkayaan stok untuk memperbaiki dan mempertahankan kelestarian sumberdaya cumi-cumi. Salah satu faktor yang sangat penting untuk mendukung upaya budidaya cumi-cumi adalah adanya ketersediaan (supply) telur dan keberhasilan pemijahan.

Kawasan Rigaih Kabupaten Aceh Jaya merupaka salah satu daerah stok cumicumi yang sangat banyak dan ditangkap oleh nelayan tradisional setempat setiap hari. Namun sampai saat ini tidak ada dilakukan budidaya dan kegiatan lain yang menyangkut menjaga keberlanjutan cumi-cumi.

Cumi-cumi biasanya memilih kedalaman perairan dan benda-benda yang terdapat dalam perairan untuk meletakkan telurnya (Brandt 1984). Cumi-cumi cenderung menempelkan telurnya pada benda berbentuk helaian atau tangkai yang letaknya agak terlindung dan tempat agak gelap (Nabhitabhata 1996). Informasi tentang musim penangkapan cumi-cumi dan adanya pemilihan cumi-cumi terhadap tempat dan benda-benda yang terdapat di dalam perairan untuk meletakkan telurnya, dapat dijadikan sebagai landasan dalam menciptakan teknik dan metode penangkapan serta atraktor untuk menarik cumi-cumi menempelkan telurnya sehingga stok cumicumi semakin banyak dan sustaineble.

Atraktor dapat dibuat dari berbagai bahan dan dapat pula diatur bentuknya sesuai dengan tujuan dari pemasangan atraktor tersebut. Hingga saat ini penggunaan atraktor untuk mempengaruhi cumi-cumi menempelkan telurnya belum banyak dilakukan. Oleh karena itu perlu dilakukan pengabdiaan ini tentang hal tersebut diantaranya adalah mengenai pengaruh perbedaan jenis dan kedalaman perairan tempat pemasangan atraktor terhadap penempelan telur cumi-cumi dengan menggunakan kawat besi yang dilapisi plastik hitam dan di ikat tali ijok di perairan Rigaih Kabupaten Aceh Jaya.

\section{METODELOGI}

Alokasi waktu pengabdian di masyarakat berlangsung dua bulan penelitian tentang atraktor cumi-cumi dan telur cumi- cumi yang menempel di aktraktor.Atraktor ini menjadi rumah buatan bagi cum-cumi untuk menempelkan telurnya yang aman dan ramah lingkungan serta kawasan Rigaih menjadi daerah yang memiliki stok cumi-cumi lebih baik yang berkelanjutan dan tanggung jawab. 


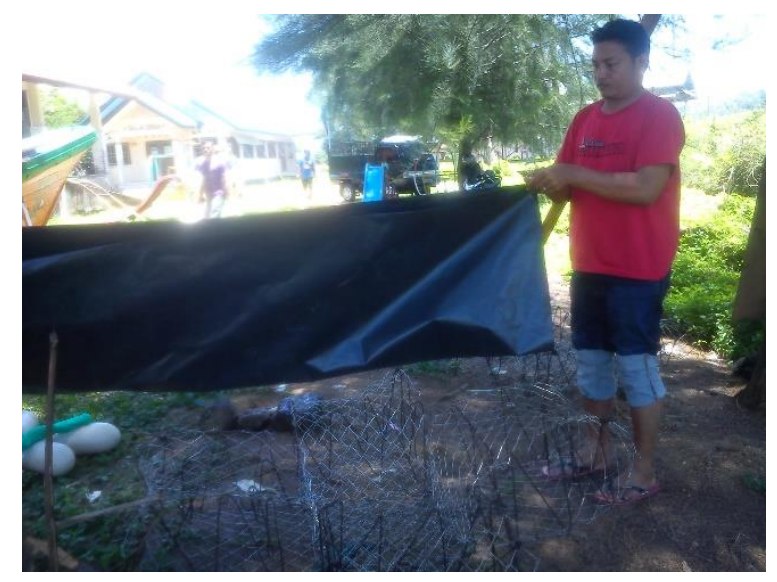

Gambar 1. Aktraktor Cumi-cumi di Rigaih

Kawat putih di gulung menyurupai bunga dan di dalam gulungan di ikat Serat ijuk dipintal menjadi tali dengan diameter $15 \mathrm{~mm}$ sepanjang $25 \mathrm{~cm}$, sebanyak 6 buah untuk setiap atraktor. Masing-masing bagian ujung dari tali ijuk diikatkan pada dua buah tali nilon $7 \mathrm{~mm}$ yang ditempatkan di bagian tengah atraktor. Kerangka atraktor terbuat dari kawatdengan ukuran panjang $50 \mathrm{~cm}$, lebar $70 \mathrm{~cm}$ dan tinggi $30 \mathrm{~cm}$. Kemudia di atas aktraktor di kasih plastik hitam supaya dalam di masukkan kedalam laut akan gelap dan nyaman bagi cumi-cumi untuk menempelkan telurnya.

\section{HASIL DAN PEMBAHASAN}

Kabupaten Aceh Jaya merupakan kabupaten pemekaran dari Kabupaten Aceh Barat yang memiliki garis pantainya $155 \mathrm{Km}$, terdiri dari sekitar 16 pulau yang sangat strategis dan yang kaya akan ekosistem serta mata pencaharian masyarakatnya $75 \%$ adalah nelayan. Berdasarkan kondisi tersebut yang memiliki kekayaan sumber daya alam (hayati dan non hayati) yang sangat potensial untuk pembangunan kesejahteraan masyarakat. Oleh karena Kabupaten Aceh Jaya khususnya di Kecamatan Rigaih dengan tekstur dasar lautnya adalah berkarang dan berlumpur maka banyak ada ekosistem yang tergolong khas dan mempunyai nilai ekonomis yang tinggi seperti berbagai jenis udang, mulossca dan lobster.

Pemasangan atraktor berupa kawat yang ditutupi dengan plastik hitam merupakan upaya manipulasi lingkungan untuk membuat ruang atraktor berada dalam keadaan tersamar atau agak gelap. Kerangka berbentuk ruang persegi empat dimaksudkan untuk menyediakan ruang perlindungan bagi telur cumi-cumi. Tulak (1999) menginformasikan bahwa cumi-cumi menempelkan telurnya secara tersembunyi pada bagian dalam ranting-ranting sponge untuk menjamin keamanan telur tersebut.

Setelah dilakukan pemasangan atraktor dan dari hasil pengamatan diketahui bahwa telur cumi-cumi cenderung menempel pada atraktor yang suka lebih gelap yang dipasang di atas dasar perairan. Telur cumi-cumi menempel pada helai tali ijuk atraktor. Telur cumi-cumi tidak menempel pada bagian lain dari aktraktor seperti penutup daritali pengikat ijuk dan tali cabang di bagian atas atraktor. 
Berdasarkan jumlah telur yang menempel pada atraktor selama pengabdian menunjukkan bahwa telur cumi-cumi paling banyak menempel pada atraktor berpenutup plastik berada di atas dasar perairan. Hal ini membuktikan bahwa cumicumi lebih suka menempelkan telurnya pada benda yang terdapat di atas dasar perairan khususnya yang berada pada lokasi agak gelap atau tersamar dan terlindung. atraktor dan kedalaman perairan tempat pemasangan atraktor menunjukkan bahwa ada pengaruh yang sangat nyata dari jenis dan kedalaman pemasangan atraktor terhadap penempelan telur cumi-cumi.

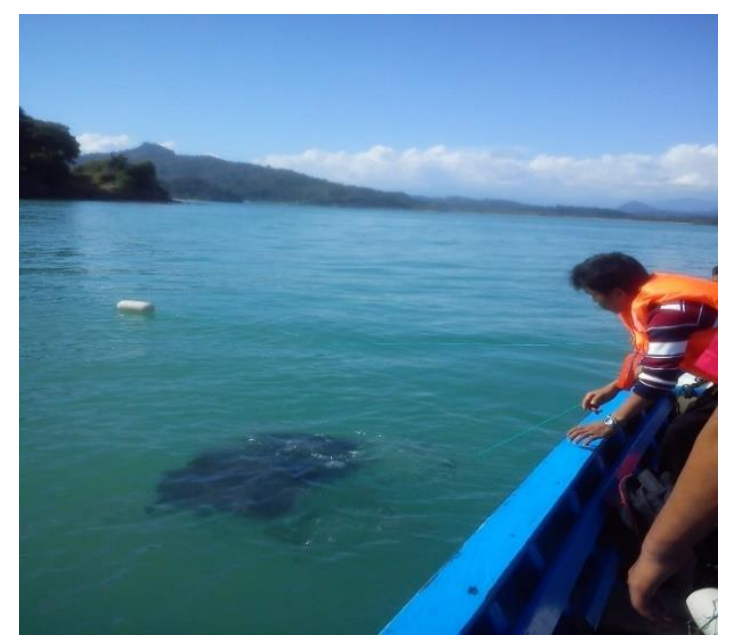

Gambar 2. Penempatan atraktor cumi-cumi di laut Rigaih

Jumlah rata-rata telur cumi-cumi yang menempel pada atraktor selama pengabdian menunjukkan adalah 112,25 terdiri dari 3 kelompok telur. Jumlah individu pada kapsul telur bervariasi yaitu antara 3 sampai 5 individu. Dalam hal ini hanya ditemukan 1 kapsul yang berisi 3 butir telur, sedangkan yang lain semuanya berisi 5 butir telur. Segawa (1987) melaporkan bahwa telur-telur tersimpan dalam kapsul dan setiap kapsul dapat mencapai 10 sampai 275 kapsul telur. Jumlah telur yang dihasilkan berkisar 41 sampai 1226 butir. Jumlah menimum telur adalah 3 butir ditemukan pada kapsul telur Sepioteuthis lessonianna. Ahmat et al. (1996) menginformasikan makanan dapat merangsang pembentukan dan penyempurnaan kapsul telur cumi- cumi. Pongsapan et al. (1995) menginformasikan bahwa kapsul-kapsul telur tersebut berwarna putih, lunak, mempunyai gelatin tipis dan tembus cahaya. Jumlah kapsul yang dihasilkan dalam sekali pemijahan berkisar 57 sampai 601 dengan jumlah telur yang terkandung di dalamnya sebanyak 124 sampai 1421 butir. Danakusumah et al. (1995) melaporkan bahwa jumlah kapsul telur cumi-cumi berkisar 380 -551 dengan jumlah telur yang terkandung di dalamnya 700 sampai 2241 butir, setiap kapsul berisi 1 sampai 6 butir.

Telur cumi-cumi yang dikoleksi dari atraktor selanjutnya dipindahkan ke dalam tempat penetasan yang berada di dalam keramba jaring apung. Telur cumi-cumi ditempatkan pada masing-masing petak berdasarkan waktu serta asal jenis atraktor dan kedalaman pemasangan atraktor tersebut. Cara meletakkan telur cumi- cumi mengikuti petunjuk dari Hamzah (1993), dimana telur cumi-cumi digantung dengan tali nilon berdiameter $5 \mathrm{~mm}$ pada kedalaman $50 \mathrm{~cm}$. Pencatatan waktu asal atraktor dimaksudkan untuk memudahkan pemantauan terhadap telur selama masa inkubasi. Telur cumi-cumi yang diinkubasi di dalam keramba jaring apung secara keseluruhan 
menetas pada hari ke-28 hingga hari ke-30. Kapsul telur yang telah menetas tampak berlubang dan mengempis. Kapsul telur yang rusak tampak masih mengembung dan berwarna gelap namun tidak berisi larva cumi-cumi. Juvenil cumi-cumi tampak berenang berkelompok. Tingkah laku juvenil pada saat makan adalah mengejar dan menangkap mangsa. Setelah mangsa tertangkap juvenil cumi-cumi berenang mundur ke belakang dengan tetap memegang mangsa.

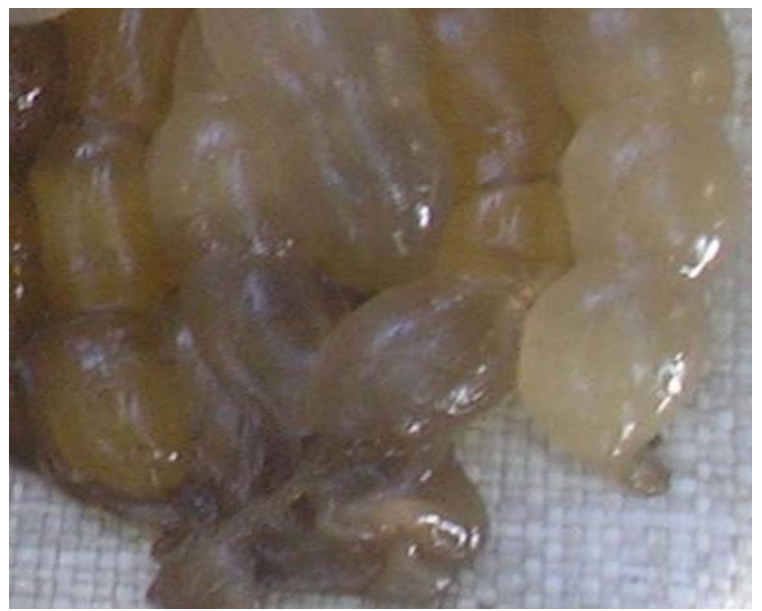

Gambar 3. Telur cumi-cumi yang menempel di atraktor

PadaGambar3tampakbahwatelurcumi-cumidi tali yang di angkat dari aktaktornya setelah ditegelamkan selama 1 bulan di kawasan teluk Rigaih.Telurcumi-cumidiupayakantidakbersentuhandengankawat aktraktor untuk menghindari kerusakan kapsul telur pada saat erjadi gerakan air akibat gelombang. Boletzky (1977) menginformasikan bahwa studi tentang perkembangan embrio dilakukan dengan menggunakan telur-telur yang berhasil diperoleh dari laut atau dengan memelihara hewan-hewan dewasa di dalam laboratorium hingga mereka memijah. Kebanyakan studi ini berakhir ketika telurtelur tersebut menetas dan pada saat mereka memiliki organ-organ yang telah berkembang dan dapat digunakan untuk bergerak aktif, mencari makanan, untuk menyembunyikan diri dan untuk melarikan diri.

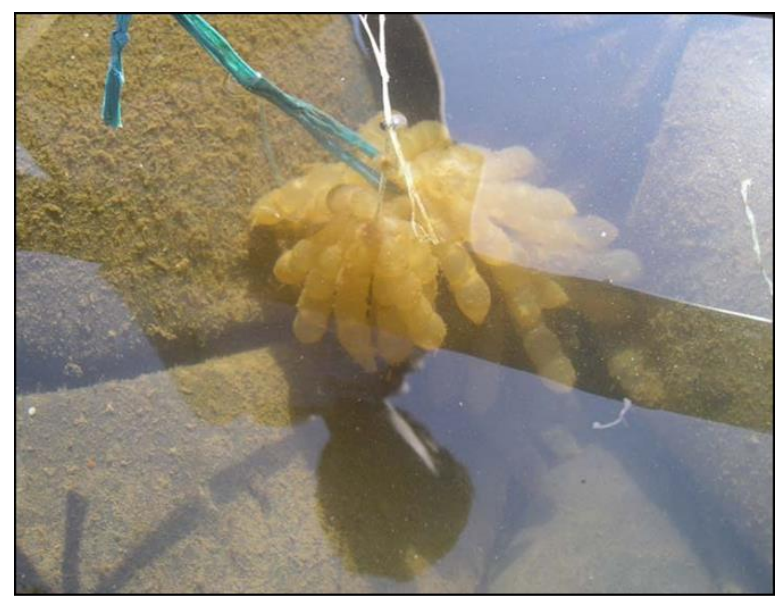

Gambar 4. Telur cumi-cumi yang mau menetas 
Berdasarkan pengamatan kondisi telur cumi-cumi di kawasan Perairan Rigaih menunjukkan bahwa pada Gambar 4 tampak bahwa telur cumi-cumi pada awalnya berwarna putih cerah berubah menjadi gelap pada saat mendekati saat menetas. Ukuran diamater telur saat mendekati waktu menetas lebih besar dari ukuran diameter awal saat telur diambil dari atraktor. Embrio cephalopoda memiliki bentuk blastula yang unik dan berbeda dengan molusca lainnya (Boletzky 1998). Embrio ini berhasil mengembangkan perlengkapan untuk mengapung yang sangat baik (Sophisticated) dari sebuah cangkang yang sederhana (Bandel dan Boletzky 1979). Mereka memiliki alat-alat indera yang sempurna serta mata dan statocyst yang sangat mirip dengan organ-organ analog pada hewan vertebrata (Boletzky 1998).

\section{PENUTUP \\ Kesimpulan}

Pengamatan yang dilakukan di Perairan Rigaih tentang uji coba atraktor cumicumi sebagai solusi bagi kondisi cumi-cumi saat ini sangat menghasilkan hasil yang bagus. Pengabdian yang dilakukan ini selama dua bulan menunjukka bahwa cumicumi mau menempelkan telurnya di aktraktor dengan kondisi yang lebih gelap dibandingkan yang terang dengan jumlah telar terbanyak mencapai 601 telur yang terdapat 1421 butir cumi-cumi.

\section{DAFTAR PUSTKA}

Ahmad, T, Gunarto, D. Pongsapan, A. G. Mangawe, M. Silele, M. I. Madeli, Muharijadi, E. Danakusumah. 1996. Penelitian Reproduksi dan Pemeliharaan Larva cumicumi Sebagai Upaya Menggali Pertumbuhan Produksi Pangan Baru. [Laporan Hasil Penelitian]. Maros : Balai Penelitian Perikanan Pantai. 27 hal.

Boletzky, S.v. 1977. The Biology of Cephalopods. Post-hatching Behaviour and More of Life in Cephalopods.England : Academic Press. P 557 - 567.

Boletzky, S.v. 1998. Cephalopod Eggs and Masses. Oceanography and Marine Biology : an Annual Review 36 : 341 - 371

Danakusumah, E. Mansur dan S. Martinus 1997. Studi Mengenai Aspek-aspek Biologi dan Budidaya Cumi-cumi Sepioteuthislessoniana. II. Pengaruh Pergantian Air Terhadap tingkat Penetasan Telur Cumi- cumi. [Makalah]. Bandar Lampung :Prosiding Seminar Nasional Biologi XV, 24-26 Juli 1997. p 868-871.

Hamzah, M.S. 1993. Pengamatan Tentang Perkembangan dan Kecepatan Penetasan Telur Sotong Buluh, Sepioteuthislessoniana LESSON Pada Dua Kedalaman yang Berbeda di TelukUn, Tual. Balai Litbang Sumberdaya Laut Puslitbang Oseanologi LIPPI Ambon. Ambon. Hal : 73-80

Tasywiruddin M.T. 1999. Sebaran dan Kelimpahan Cumi-cumi (Loligoedulis Hoyle, 1885) berdasarkan jumlah dan posisi lampu pada operasi penangkapan dengan paying oras di perairan selat Alas, Nusa Tenggara Barat. [Thesis]. Bogor: Program Pascasarjana, InstitutPertanian Bogor. 52 hal. 
Tulak, D. C, 1999. Pengamatan Substrat Penempelan Telur Cumi-cumi Sirip Besar (Sepioteuthislessoniana, LESSON ) di Habitat Pemijahan Perairan Teluk Banten. [Skripsi]. Bogor :Fakultas Perikanan, Institut Pertanian Bogor. 34 hal. 